\title{
PEMANFAATAN DAUN KELOR SEBAGAI MINUMAN HERBAL DALAM RANGKA MENCEGAH PENYEBARAN COVID-19
}

\author{
Marten Umbu Nganji ${ }^{*}$, Lusia Danga Lewu ${ }^{1}$, Uska Peku Jawang ${ }^{1}$, \\ Yonce M. Killa ${ }^{1}$, Sri Ita Tarigan ${ }^{1}$ \\ ${ }^{1}$ Program Studi Agroteknologi, Universitas Kristen Wira Wacana Sumba \\ email:*martenngannji@unkriswina.ac.id
}

\begin{abstract}
Moringa leaves can be processed in various food and beverage products such as clear vegetables, juice, omelette, chips, nastar, donuts, bakwan and Moringa leaf noodles. In addition, Moringa leaves can be processed as herbal drinks. Currently, with the covid-19 pandemic conditions around the world, many alternative herbal ingredients are consumed by the public to increase body nutrition in order to prevent transmission of the virus, one of which is Moringa leaves. Moringa plants are high in nutrients, such as vitamin C, calcium, vitamin A, potassium, and protein. The purpose of implementing this PkM activity is to provide information and, to provide assistance to the community in utilizing Moringa plants to prevent Covid-19, as well as to improve community skills in making Moringa herbal drink to prevent Covid-19. This PkM was held at the Ori Angu Farmers Group in Pambotanjara Village, with a series of activities including the socialization of the importance of Moringa leaves, the preparation of raw materials for making herbal moringa drinks, and the practice of manufacturing Moringa leaf herbal drink products. The results of this activity were the socialization of the use of Moringa leaves as a way to increase immunity in order to prevent viruses and the practice of making Moringa leaf tea with members of farmer groups, students and lecturers at the Ori Angu Farmer Group, Pambotanjara Village.
\end{abstract}

Keywords: herbal drink; moringa leaves; prevents covid-19

\begin{abstract}
Abstrak: Daun kelor dapat diolah dalam berbagai produk makanan dan minuman seperti sayur bening, juice, omelet, keripik, nastar, donat, bakwan dan mie daun kelor. Selain itu, daun kelor dapat diolah sebagai minuman herbal. Saat ini, dengan adanya kondisi pandemik covid-19 di seluruh dunia, banyak alternatif bahan herbal yang dikonsumsi oleh masyarakat untuk menambah nutrisi tubuh agar dapat mencegah terjadinya penularan virus tersebut, salah satunya adalah daun kelor. Tanaman kelor memiliki nutrisi tinggi, seperti vitamin $\mathrm{C}$, kandungan kalsium, vitamin A, kandungan potasium, dan protein. Tujuan pelaksanaan kegiatan PkM ini adalah untuk memberikan informasi dan, melakukan pendampingan kepada masyarakat dalam memanfaatkan tanaman kelor untuk mencegah covid-19, serta meningkatkan keterampilan masyarakat dalam pembuatan minuman herbal daun kelor dalam mencegah covid-19. PkM ini dilaksanakan di Kelompok Tani Ori Angu Desa Pambotanjara dengan runtutan kegiatan adalah sosialisasi pentingnya daun kelor, persiapan bahan baku pembuatan minuman herbal daun kelor, dan praktik pembuatan produk minuman herbal daun kelor. Hasil dari kegiatan ini adalah terlaksananya sosialisasi pemanfaatan daun kelor sebagai salah satu cara menambah imunitas tubuh dalam rangka mencegah virus dan dilaksanakannya praktik pembuatan teh daun kelor bersama anggota kelompok tani, mahasiswa dan dosen di Kelompok Tani Ori Angu Desa Pambotanjara.
\end{abstract}

Kata kunci: daun kelor; mencegah covid-19; minuman herbal 
Jurdimas (Jurnal Pengabdian Kepada Masyarakat) Royal

Vol. 4 No. 2, Mei 2021, hlm. 189 - 196

ISSN 2614-7912 (Print)

DOI: https://doi.org/10.33330/jurdimas.v4i2.1072

ISSN 2622-3813 (Online)

Available online at https://jurnal.stmikroyal.ac.id/index.php/jurdimas

\section{PENDAHULUAN}

Dunia sedang dilanda dengan hadirnya wabah penyakit yang disebut Covid-19. Penyakit yang ditimbulkan oleh infeksi virus SARS-CoV-2 tersebut pertama kali teridentifikasi di Kota Wuhan, Provinsi Hubei Cina pada bulan Desember 2019. Covid-19 sebelumnya dikenal sebagai Novel Coronavirus, sebelum WHO me-nyatakan nama secara resmi sebagai Covid-19 pada bulan Februari 2020 (Huang, Wang, Li, Ren, Zhao, \& Hu, 2020; Wu, Chen, \& Chan, 2020; \& Putri, 2020). Pada tanggal 30 Januari 2020, WHO menyatakan bahwa virus corona 2019-2020 sebagai Kesehatan Masyarakat Darurat Internasional (PHEIC), dan menyatakan pandemik pada 11 Maret 2020. Hampir 200 negara di dunia tertular virus corona, dan Indonesia adalah salah satu negara yang mengalami (Supriatna, 2020).

Penyebaran Covid-19 sangat cepat dan angka kematian terus meningkat berbagai negara termasuk Indonesia. Kasus terinfeksi virus korona di Indonesia bertambah secara cepat, dilaporkan hingga Juni 2020 terdapat 31.186 kasus positif dan 1.851 kasus meninggal (PHEOC Kemenkes RI, 2020). DKI Jakarta merupakan provinsi dengan kasus covid-19 tertinggi yaitu sebesar 7.623 kasus dan 523 (6,9\%) kasus kematian (PHEOC Kemenkes RI, 2020; lihat Putri, 2020).

Penularan yang terjadi secara langsung antar manusia menimbulkan penambahan kasus positif yang banyak, misalnya akhir Januari 2020 dilaporkan terjadinya penambahan 2.000 kasus terkonfirmasi dalam 24 jam (Handayani, Hadi, Isbaniah, Burhan, \& Agustin, 2020).

Virus corona diperkirakan dapat ditularkan melalui cairan yang dihasilkan dari batuk, bersin, menyentuh permukaan yang telah terkontaminasi dan selanjutnya menyentuh area wajah maupun kontak lansung melalui ciuman dan berjabatan tangan. Gangguan pernapasan, demam, batuk dan sesak napas merupakan gejala awal terinfeksi Covid19. Pernapasan akut, Pneumonia, gagal ginjal, dan bahkan kematian adalah penyebab yang ditimbulkan pada kasus Covid-19 dengan gejala berat (Wulandari, Rahman, Pujianti, Sari, Laily, Anggraini, ... \& Prasetio, 2020).

Provinsi Nusa Tenggara Timur merupakan provinsi yang berada di bagian timur Indonesia. Daerah ini tidak luput dari penyebaran Covid-19 yang tersebar di hampir seluruh kabupaten. Data gugus tugas terbaru tanggal 9 April 2020 menunjukkan satu kasus baru terdapat di NTT. Dengan adanya kasus di NTT ini, artinya penularan covid-19 telah menyebar ke 33 provinsi di Indonesia (Rozie, 2020). Provinsi NTT hingga saat ini baru ditemukan 1 pasien yang termasuk dalam status positif, sedangkan yang lainnya masih dalam status orang dalam pemantauan dan pasien dalam pengawasan.

Kabupaten Sumba Timur adalah kabupaten yang ada di Provinsi NTT. Menurut data yang dilaporkan oleh Satuan Tugas Covid-19 Dinkes Sumba Timur bahwa Kabupaten Sumba Timur adalah daerah penyumbang ODP. Update terkait ODP covid-19 di Kabupaten Sumba Timur sampai dengan tanggal 29 Maret 2020 pukul 16.00 Wita dilaporkan bertambah jadi 33 kasus. Setelah sebelumnya pada tanggal 28 Maret 2020 pukul 16.00 Wita dilaporkan 28 kasus. Hal ini disampaikan oleh Tim Posko Covid-19 Dinkes Sumba Timur yang di share ke akun facebook Posko Covid Sumba Timur. Dalam data tersebut dijelaskan, untuk pelaku perjalanan dari 
Available online at https://jurnal.stmikroyal.ac.id/index.php/jurdimas

daerah terpapar sebanyak 391 orang. Dari 391 pelaku perjalanan itu, 33 diantaranya ODP, sedangkan pasien dalam pengawasan (PDP) nihil, begitu juga dengan pasien positif covid- 19 nihil.

Menghadapi penyebaran covid-19 yang terus meningkat, maka tindakan pecegahan terus dilakukan. Salah satu himbauan pemerintah dalam rangka melindungi diri dari terjangkitnya virus adalah menjaga imun tubuh. Tubuh yang berimun tinggi, mengurangi risiko terjangkitnya berbagai virus. Salah satu cara pencegahan yang dapat dilakukan yaitu dengan mengkonsumsi minuman herbal yang terbuat dari bahan lokal yang terdapat disekitar kita dalam bentuk juice, jamu, seduhan teh maupun dalam bentuk lainnya.

Daun kelor merupakan salah satu bahan minuman herbal yang saat ini sedang ramai diperbincangkan baik dari kalangan pemerintah maupun masyarakat dan dianjurkan untuk dikonsumsi selama masa darurat covid-19. Daun kelor (Moringa oleifera Lamk.) merupakan tanaman yang kandungan nutrisinya sangat banyak dan semua bagian tanaman kelor sangat berguna bagi tubuh dan juga dapat meningkatkan ekonomi keluarga (Jusnita \& Syurya, 2019).

Selain nutrisi tanaman kelor banyak, kelor juga adalah jenis tanaman yang terdapat banyak antioksidan. Antioksidan pada tanaman kelor merupakan salah satu yang paling menonjol, terutama pada bagian daun. Menurut (Yuliani \& Dienina, 2015) antioksidan dapat mencegah pengaruh ancaman radikal bebas atau Reactive Oxygen Species yang terbentuk sebagai hasil dari metabolisme oksidatif yaitu hasil dari reaksi-reaksi kimia dan proses metabolik yang terjadi dalam tubuh. (Rahmawati \& Adi, 2016) menyatakan dalam penelitiannya bahwa satu gram daun kelor kering mengandung vitamin A 10 kali lebih banyak dari wortel, kalsium 17 kali lebih banyak dari susu, zat besi 25 kali lebih banyak dari bayam, protein 9 kali lebih banyak dari yogurt, dan potassium 15 kali lebih banyak dari pisang.

Berdasarkan dengan pertimbangan kondisi darurat covid-19, Universitas Kristen Wira Wacana Sumba juga merasa sangat penting untuk berpartisipasi dalam menyalurkan ilmu tentang pencegahan covid-19 khususnya dalam pemanfaatan tanaman obat melalui kegiatan Pengabdian kepada Masyararakat. Kegiatan ini dilakukan oleh para tenaga pendidik program studi Agroteknologi dengan judul "Pemanfaatan Daun Kelor Sebagai Minuman Herbal Dalam Rangka Mencegah Penyebaran Covid-19".

\section{METODE}

Kegiatan PkM dilaksanakan di Kelompok Tani Ori Angu Desa Pambotanjara. Kegiatan ini dilakukan dengan melibatkan anggota kelompok tani (15 orang), mahasiswa (10 orang) dan dosen Program Studi Agroteknologi (5 orang).

Penentuan lokasi PkM di desa Pambotanjara, kecamatan Kota Waingapu diawali dengan survei yang dilakukan oleh dosen program studi untuk mengetahui potensi dan permasalahan yang terjadi di kelompok tani. Hasil survey menunjukkan bahwa Kelompok Tani Ori Angu sangat antusias dengan program sosialisasi dan pembuatan produk olahan dari daun kelor yang akan dilaksanakan, karena anggota kelompok tani tersebut sudah melakukan budidaya kelor tapi mereka belum 
memanfaatkan dengan baik atau belum melakukan inovasi-inovasi produk dari dalam kelor yang dapat menambah nilai jual dari daun tersebut. Pandemi covid-19 juga merupakan bentuk pertimbangan dalam mengolah daun kelor menjadi minuman herbal karena kandungan nutrisi dan antioksidannya yang sangat berguna dalam pencegahan penularan covid-19. Berdasarkan hasil survey tersebut, maka dosen Program Studi Agroteknologi mengajukan proposal ke Program studi Agroteknologi dan membentuk tim untuk melaksanakan pengabdian kepada masyarakat terkait pemanfaatan dan inovasi produk daun kelor menjadi salah satu minuman herbal dengan tujuan untuk mencegah penyebaran covid-19 sekaligus meningkatkan ekonomi petani.

Kegiatan ini memiliki konsep dasar yaitu memanfaatkan daun kelor sebagai salah satu olahan minuman herbal untuk menambah imun tubuh dan mencegah penyebaran virus. Tahapantahapan pelaksanaan PkM yaitu; pertama, survey lokasi dan kesepakatan waktu pelaksanaan kegiatan yang dilakukan oleh dosen dan pengurus kelompok tani. Kedua, sosialisasi dan penyampaian materi yang dilakukan oleh dosen Program Studi Agroteknologi. Materi yang disosialisasikan adalah teknik budidaya tanaman kelor, kegunaan daun kelor, dan teknik pembuatan minuman herbal dari daun kelor. Ketiga, pendampingan dan latihan bersama tentang cara penyortiran serta persiapan daun kelor siap pakai. Kegiatan ini dilakukan oleh anggota kelompok tani, mahasiswa dan staf pendidik. Staf pendidik sebagai fasilitator dalam proses mempersiapkan bahan untuk pembuatan minuman herbal daun kelor. Keempat, praktik pembuatan minuman herbal dari daun kelor. Kegiatan pembuatan daun kelor sebagai minuman herbal dilakukan secara bersama-sama oleh anggota kelompok, mahasiswa dan staf pendidik dari program studi Agroteknologi.

\section{PEMBAHASAN}

\section{Pembukaan dan Sosialisasi Kegiatan PkM}

Pembukaan PkM Prodi Agroteknologi dilaksanakan pada Kantor desa Pambotanjara. Kegiatan PkM dibuka oleh Ketua Program Studi Agroteknologi, dilanjutkan dengan penjelasan singkat terkait pelaksaan $\mathrm{PkM}$ oleh ketua Tim. Acara pembukaan juga diikuti dengan penyampaian beberapa materi penting terkait budidaya dan pengolahan tanaman kelor yang di pandu oleh dosen-dosen Prodi Agroteknologi.

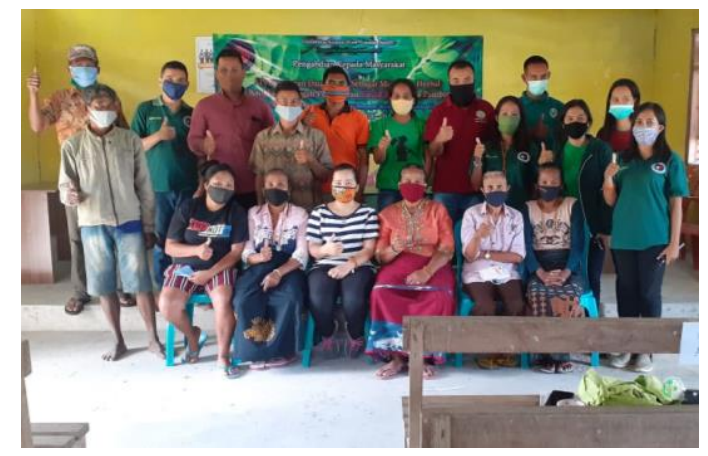

Gambar 1. Foto bersama setelah dilakukannya sosialisasi kegiatan PkM

\section{Proses Persiapan Daun Kelor Menjadi Teh}

Bahan baku pembuatan daun teh kelor diambil dari lahan petani sebanyak $\pm 20 \mathrm{~kg}$ kemudian dipisahkan dari tangkainya. Selanjutnya dilakukan Penyortiran bahan baku. Kegiatan ini dilakukan oleh peserta PkM yaitu memisahkan daun kelor segar, sedangkan yang berwarna kuning hingga coklat dibuang. Hal ini bertujuan agar diperoleh daun kelor dengan tampilan yang 
Jurdimas (Jurnal Pengabdian Kepada Masyarakat) Royal

Vol. 4 No. 2, Mei 2021, hlm. 189 - 196

DOI: https://doi.org/10.33330/jurdimas.v4i2.1072

Available online at https://jurnal.stmikroyal.ac.id/index.php/jurdimas

seragam.

Daun kelor yang telah disortir kemudian dicuci pada wadah yang sudah terisi air atau air mengalir. Pencucian dilakukan untuk menghilangkan kotoran dan debu. Selanjutnya daun kelor ditiriskan selama 24 jam untuk menghilangkan sisa air pencucian. Selanjutnya daun kelor yang telah ditiriskan dijemur di sinarmatahari terik. Proses ini dilakukan di bawah naungan menggunakan plastik paranet yang bertujuan agar daun kelor tidak terpapar secara langsung oleh sinar matahari.

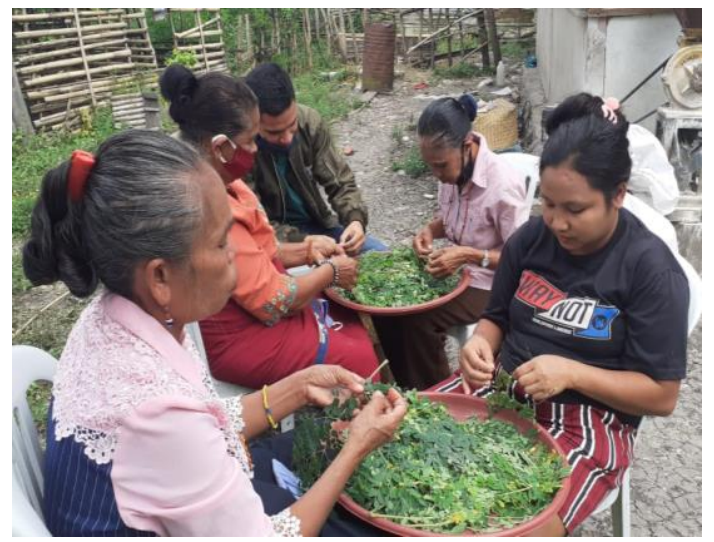

Gambar 2. Proses penyortiran daun kelor

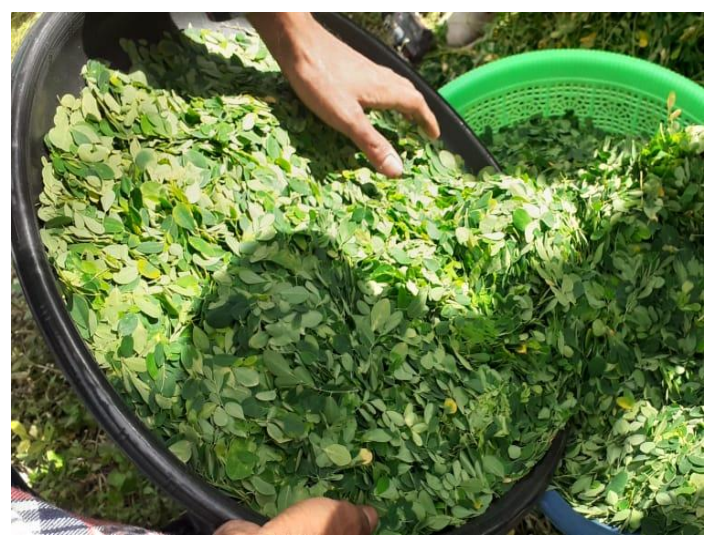

Gambar 3. Hasil penyortiran daun kelor

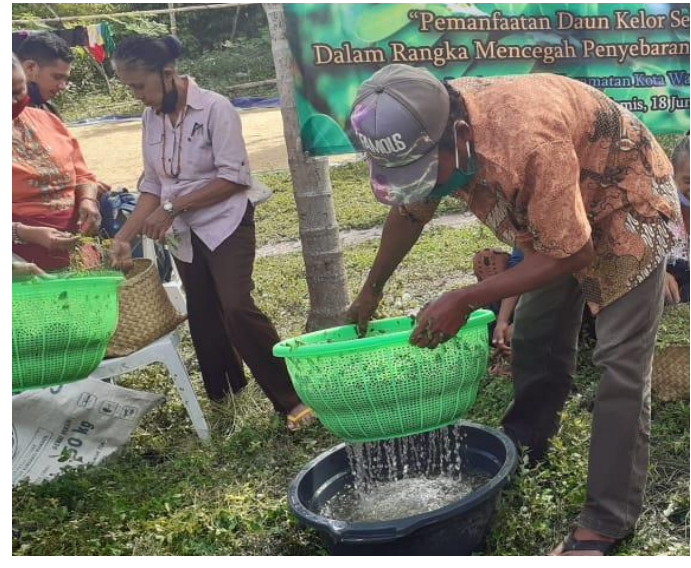

Gambar 4. Proses pencucian daun kelor

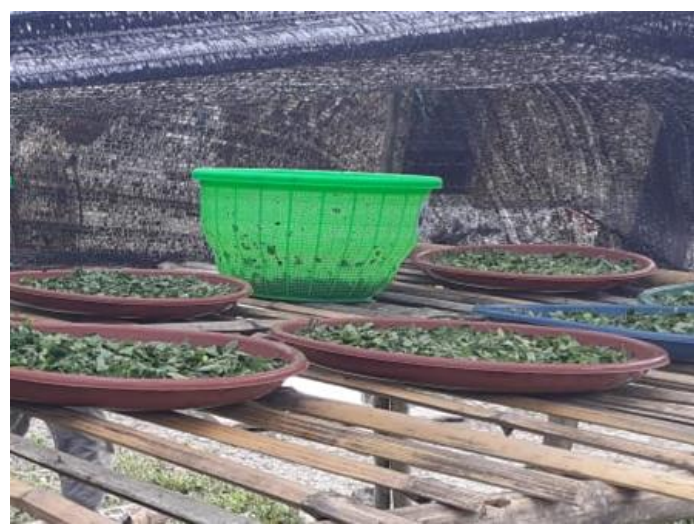

Gambar 6. Proses pengeringan daun kelor

\section{Pengamatan Selama Pengeringan Daun Kelor}

Pengamatan proses pengeringan daun kelor dilakukan setiap 2 hari sekali oleh tim PkM. Kegiatan ini dilakukan untuk memastikan daun kelor yang dijemur dapat kering secara merata.

\section{Proses pembuatan minuman herbal dari daun kelor}

Siapkan \pm 100 gr daun kelor kering dan rebus dalam 2 liter air (wadah perebusannya dibiarkan terbuka). Biarkan mendidih selama 30 menit, kemudian tambahkan gula jawa dan potongan batang sereh secukupnya. Jika telah matang, lakukan penyaringan agar 
Jurdimas (Jurnal Pengabdian Kepada Masyarakat) Royal Vol. 4 No. 2, Mei 2021, hlm. 189 - 196

Available online at https://jurnal.stmikroyal.ac.id/index.php/jurdimas

diperoleh oleh air rebusan yang jernih. Siap disajikan (dapat dikonsumsi dalam keadaan hangat maupun dingin menggunakan es batu).

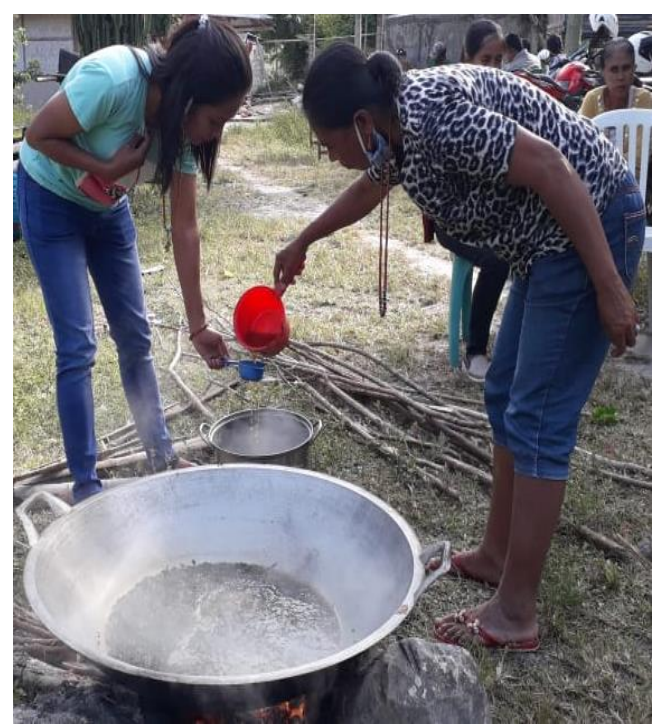

Gambar 7. Proses pemasakan minumal herbal daun kelor

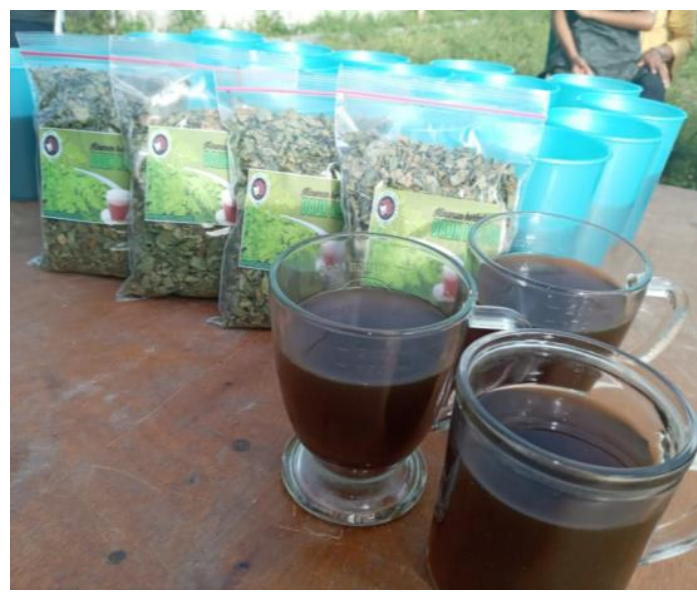

Gambar 8. Minuman herbal daun kelor siap saji

\section{Pengemasan daun kelor kering}

Pengemasan dilakukan dengan menggunakan wadah plastik (setiap 1 kemasan berisi $25 \mathrm{gr}$ ).

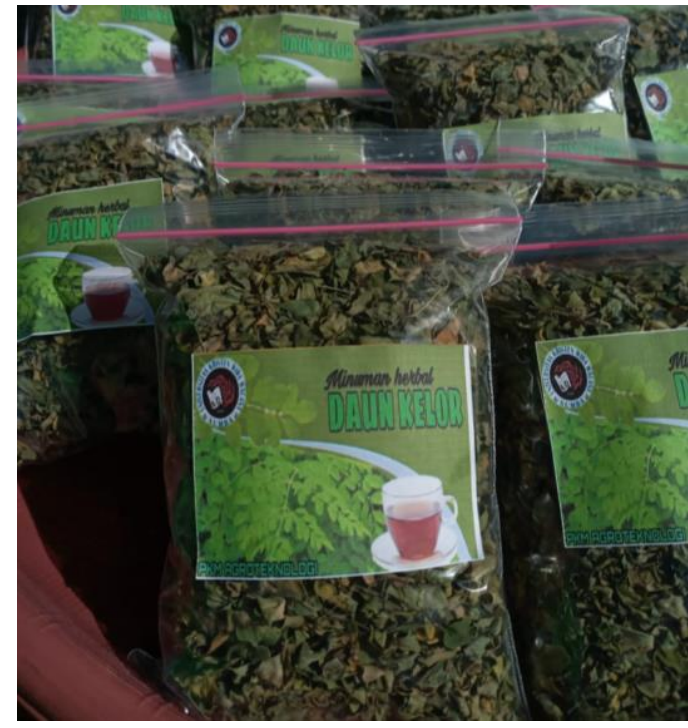

Gambar 9. Hasil pengemasan daun kelor

\section{Pembagian Kemasan Daun Kelor}

Daun kelor yang telah dikemas akan diberi label dan siap dibagikan ke peserta PkM dan masyarakat sekitar lokasi PkM.

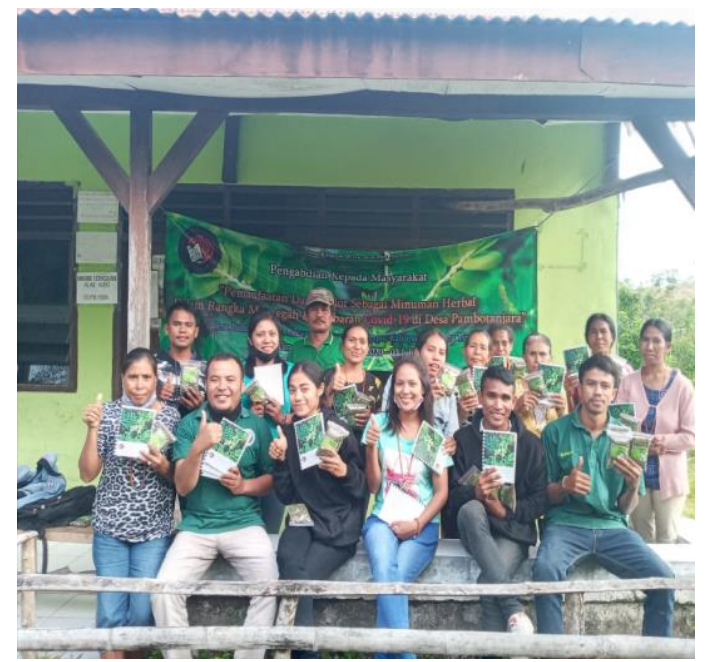

Gambar 10. Pembagian kemasan daun kelor dan buku panduan cara pembuatan minuman herbal daun kelor 


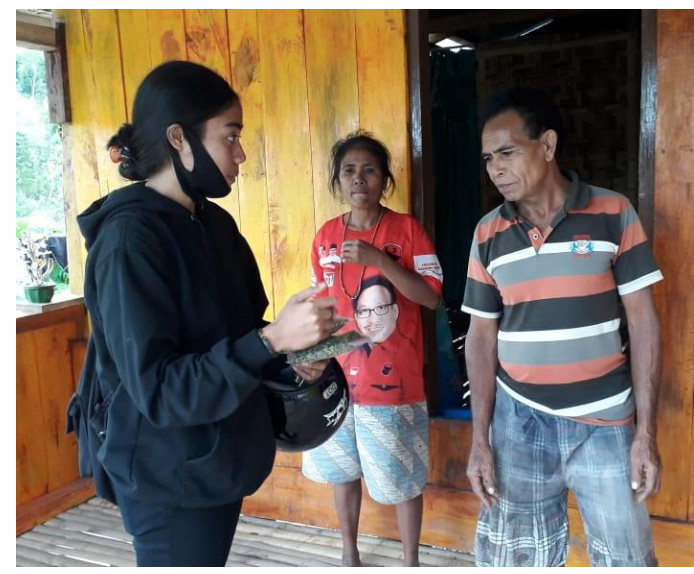

Gambar 11. Pembagian kemasan daun kelor kepada warga di sekitar lokasi kegiatan PkM

\section{SIMPULAN}

Kegiatan Pengabdian kepada Masyarakat dilakukan untuk memberikan pemahaman dan mengimplementasikan proses pembuatan minuman herbal dari daun kelor kepada anggota kelompok tani Ori Angu. Kegiatan sosialisasi dan pembuatan minuman herbal daun kelor diikuti secara antusias oleh anggota kelompok tani dari awal kegiatan sampai akhir kegiatan. Proses pembuatan minuman herbal dari daun kelor sudah dapat dilakukan oleh anggota kelompok atas bimbingan dosendosen program studi Agroteknologi.

\section{DAFTAR PUSTAKA}

Handayani, D., Hadi, D. R., Isbaniah, F., Burhan, E., \& Agustin, H. (2020). Corona virus disease 2019. Jurnal Respirologi Indonesia, 40(2), 119129.

Huang, C., Wang, Y., Li, X., Ren, L., Zhao J., \& Hu, y. (2020). Clinical features of patients infected with
2019 novel coronavirus in Wuhan, China., Lancet, Doi: 10.1016/S0140-6736(20)30183-5.

Jusnita, N., \& Syurya, W. (2019). Karakterisasi Nanoemulsi Ekstrak Daun Kelor (Moringa oleifera Lamk.). Jurnal Sains Farmasi \& Klinis, Vol. 6 No. 1 (April 2019)| pp. 16-24.

Putri, R Ni. (2020). Indonesia dalam Menghadapi Pandemi Covid-19. Jurnal Ilmiah Universitas Batanghari Jambi, 20(2), Juli 2020, 705-709.

Rahmawati, P. S., \& Adi, A C. (2016). Daya Terima dan Zat Gizi Permen Jeli Dengan Penambahan Bubuk Daun Kelor (Moringa oleifera). Media Gizi Indonesia, Vol. 11, No. 1 Januari-Juni 2016: hlm. 86-93.

Rozie, F. (2020). Tembus 33 Provinsi, Satu Kasus Baru Covid-19 Ditemukan di NTT.

Suprianta, E. (2020). Wabah Corona Virus Disease Covid 19 Dalam Pandangan Islam. Salam: Jurnal Sosial dan Budaya Syar-i. Volume 7 Nomor 6 (2020). ISSN: 2356-1459. E-ISSN: 2654-9050557.

Wu Yi-Chi., Chen C.S., \& Yu Jiun Chan. (2020). The Outbreak of Covid-19 : An overview. J Chin Med Association. Taipei.Taiwan

Wulandari, A., Fauzie, R., Nita, P., Ayu, R. S., Nur, L., Lia, A., Farid, I. M., Agus, M. R., Vina, Y. A., Muhammad, A., \& Diki, B. P. (2020). Hubungan Karakteristik Individu Dengan Pengetahuan tentang Pencegahan Coronavirus Disease 2019 pada Masyarakat di Kalimantan Selatan. Jurnal Kesehatan Masyarakat Indonesia, 
Jurdimas (Jurnal Pengabdian Kepada Masyarakat) Royal

Vol. 4 No. 2, Mei 2021, hlm. 189 - 196

ISSN 2614-7912 (Print)

DOI: https://doi.org/10.33330/jurdimas.v4i2.1072

ISSN 2622-3813 (Online)

Available online at https://jurnal.stmikroyal.ac.id/index.php/jurdimas

Volume 15, Nomor 1, Halaman 42-46, 2020.

Yuliani, N. N., \& Desmira, P. D. (2015).

Uji Aktivitas Antioksidan Infusa

Daun Kelor (Moringa oleifera,
Lamk) dengan Metode1,1diphenyl-2-picrylhydrazyl (DPPH). Jurnal Info Kesehatan, vol. 14, nomor 2 desember 2015. 